\title{
THE IMPACT OF DISTRIBUTED GENERATION ON DISTRIBUTION NETWORKS
}

\author{
A. 0. Ekwue1, ${ }^{*}$ and 0. A. Akintunde ${ }^{2}$ \\ 1 JACOBS ENGINEERING INC/BRUNEL UNIVERSITY LONDON, UNITED KingDOM \\ 2 BRUNEL UNIVERSITY LONDON, UNITED KINGDOM \\ Email addresses: ${ }^{1}$ arthur.ekwue@brunel.ac.uk, ${ }^{2}$ tobakin01@yahoo.com
}

\begin{abstract}
Distributed Generators (DG or embedded generators) are generators that are connected to the distribution network. Their advantages are the ability to reduce or postpone the need for investment in the transmission and distribution infrastructure when optimally located; the ability to reduce technical losses within the transmission and distribution networks as well as general improvement in power quality and system reliability. This paper highlights the benefits of distributed generation by using a 15-bus radial distribution network, modelled in the DIgSILENT Power Factory software, to demonstrate the improvement in voltage profile as well as the reduction in technical losses.
\end{abstract}

Keywords: distributed generation; wind energy; integration of renewable sources and technical losses.

\section{INTRODUCTION}

Distributed Generators (DG or embedded generators) are generators that are connected to the distribution network. Their advantages are the ability to reduce or postpone the need for investment in the transmission and distribution infrastructure when optimally located;the ability to reduce technical losses within the transmission and distribution networks as well asgeneral improvement in power quality and system reliability.

However, the development of renewable energy sources (e.g. wind or solar energy) and subsequent integration with the distribution network will increase the amount of generation so connected and this raises some technical issues such as [1]:

- inadvertent islanding where a section of a distribution network is to be split off the transmission network and is still energised by its embedded generators.

- the reversal of power flows which means that existing protection (if it is directional) cannot be used hence the need to install a new protection system.

- the connection of renewable generation can raise the fault levels due to the fault contributions from the renewable generators themselves to values beyond the capacity of existing switchgear. This will result in the installation of new circuit breakers which can be expensive. In order to ensure proper operation of power system protection schemes, it is necessary to provide proper and cost-efficient solutions for limiting the fault levels to their equipment capacity.

- Potential reactive power issues. This is because current wind generation technology, for example, has different electrical characteristics from conventional thermal, nuclear and hydro plants when large numbers of wind generators are installed on the network. The use of induction generators in place of the traditional synchronized generators will deliver a significant increase in reactive power and it is important that this is properly managed by the network operators. The increased reactive power on the network may prevent the connection of further wind generators to the network unless active steps are taken to absorb the reactive power.

- Fault Ride-Through Capabilities - As the penetration of renewable generation such as wind energy increases, the need to address the fault ride-through capability issues will become more critical. Hitherto, the wind turbines were allowed to trip when a 
voltage dip occurs. The wind turbines will now be expected to remain connected to the grid both during and after a fault. Upon voltage recovery, the wind turbines are not expected to consume excessive reactive power when re-exciting the generator, as this may result in a further voltage dip. This subject has been addressed elsewhere in [1].

Despite these technical challenges, many countries are reducing the greenhouse emissions and increasing the proportion of new forms of electricity generation [2]; the United Nations General Assembly has declared $2014-2024$ as the decade for sustainable energy. A recent report from the International Energy Agency [3] showed that the use of renewable energy grew strongest last year and now produces about $22 \%$ of the global consumption of electricity. The UK, for example, imports nearly $50 \%$ of the coal it uses and it is also looking for new sustainable energy solutions for the future. Renewables will help avoid dependence on imports and make the country less vulnerable to security threats. The electricity generation via renewables increased by $27 \%$ during June 2011 and June 2012 to 38 TWh [4]. By 2020 UK hopes to provide $15 \%$ of its energy consumption from renewable sources.

Japan is the world's third largest economy and its energy policy is now centered on renewablesbecause these sources are regenerative and for practical purposes cannot be depleted. Hitherto Germany relied on nuclear power for $23 \%$ of its energy. However, as a result of the Fukushima incident and following mass anti-nuclear protests across Germany, the government announced a reversal of policy that will see all of their nuclear plants phased out by 2022. Germany is now basing its energy policy not on nuclear but on renewables.According to Belgovic (2011) in [5], the growth in renewables in the first quarter of 2011 in the USA was $25.82 \%$ whereas the growth of solar energy in 2011 was $104.8 \%$.

South Africa has set a target of 10,000 GWh for renewable energy whereas the Government of Kenya is working with the International Renewable Energy Agency to explore its potentials in this area [3]. In Nigeria, the Ministry of Power [6,7] have identified the continued development of renewables and its integration to the grid as part of its future strategy.

Against this background, the objectives of this paper are to highlight the benefits of distributed generation by using a 15-bus radial distribution network, modelled in theDIgSILENT Power Factory software,todemonstrate the improvement in voltage profile as well as the reduction in technical losses. The modelling is presented in the next Section whereas the results are discussed in Section 3.

It is pertinent to mention that losses can be classified as technical or non-technical losses (comprising of illegal connections of electricity, metering errors and deficiencies, billing and processing errors etc); the subject of non-technical losses have been discussed elsewhere in [10] by Nwodo and Ekwue (1992).

\section{TEST SYSTEM MODELLED IN DIGSILENT POWER FACTORY SOFTWARE}

\subsection{DIgSILENT Power Factory software}

DIgSILENT $^{1}$ is a private company, headquartered in Gomaringen near Stuttgart, Germany and provides power system analysis software and related consultancy services. PowerFactory is its principal software offering, and is a wide-ranging PC based power system analysis package.

PowerFactory is suited to industrial, transmission and distribution networks, power plants as well as marine and aerospace industries. It was developed in Germany where it has been used very successfully, especially with the modelling of wind farms (their Doubly-Fed Induction Generator model was one of the first to be produced, and has been refined since) [12].

PowerFactoryhas the following capabilities[12]: balanced and unbalanced power flow; short circuit based on IEC 60909, VDE 0102/0103, ANSI C37 standards; transient stability; optimal power flow; low voltage network analysis etc. The software is suitable for this Study because:

- ithas the ability to analyse the impact of distributed generation on the network, and its generator models include induction machines, doublyfed induction generators, fuel cells, micro-turbines, PV-cells, wind turbines, battery storage and singlephase machines.

- $\quad$ it is suitable for radial distribution networks. In radial distribution networks, the Jacobian matrix of the load flow equationsis usually ill-conditioned as a result of lack of diagonal dominance due to the high $\mathrm{R} / \mathrm{X}$ ratio of distribution lines.

\subsection{Radial Distribution Network}

A 15-node radial distribution network sourced fromreference [8] was modelledin the DIgSILENT Power Factory software as shown in Figure 1. Table 1

${ }^{1}$ http://www.digsilent.de/ 
represents the bus data whereas the line data is embedded in Table 3 below. Table 2 shows the assumptions made for the DIgSILENT model.

Table 1: Nodal Data [8]

\begin{tabular}{cc}
\hline Node No & Load $(\mathrm{kW}+\mathrm{jkVAr})$ \\
\hline $2,5,10,12$ & $44.10+\mathrm{j} 44.99$ \\
$3,7,9,11,15$ & $70.00+\mathrm{j} 71.41$ \\
$4,6,8,13,14$ & $140+\mathrm{j} 142.82$ \\
\hline
\end{tabular}

Table 2: Assumptions made in DIgSILENT Power Factory software

\begin{tabular}{ll}
\hline \multicolumn{1}{c}{ Parameter/System } & \multicolumn{1}{c}{ Assumptions } \\
\hline Distribution line & Ground laying \\
Length of line & 1 kilometre for each branch \\
Line model & Lumped parameter (Pi) \\
Load type & Constant power \\
Nominal frequency & $50 \mathrm{~Hz}$ \\
System type & $3-$ phase AC \\
Rated voltage & $12 \mathrm{kV}$ \\
Nominal voltage & $11 \mathrm{kV}$ \\
& Upper limit - 1.055 per unit \\
Voltage limits & Lower limit - 0.95 per unit \\
Bus 1 & Slack or reference bus \\
\hline
\end{tabular}

The total system calculation report before the installation of the DG is shown in Figure 2.

Some of the methods of integrating wind energy to a network have been described in [9] as:

- use of classical squirrel cage induction wind turbine generators (WTG).

- use of induction WTGs with dynamic slip control.

- induction or synchronous WTGs connected through power electronic converters.

- Doubly Fed Induction Generators (DFIG).

A synchronous generator representing a modern offshore wind turbine (as a DG) was modelled in DIgSILENT Power Factory software(Figure 3) and placed separately on buses 2 and 4 to investigate the impact of losses.The choice of these buses is arbitrary hence the authors have identified the need for further studies to account for the optimal allocation of DG. The wind turbine is assumed to generate $60 \%$ active power and $40 \%$ of reactive power.

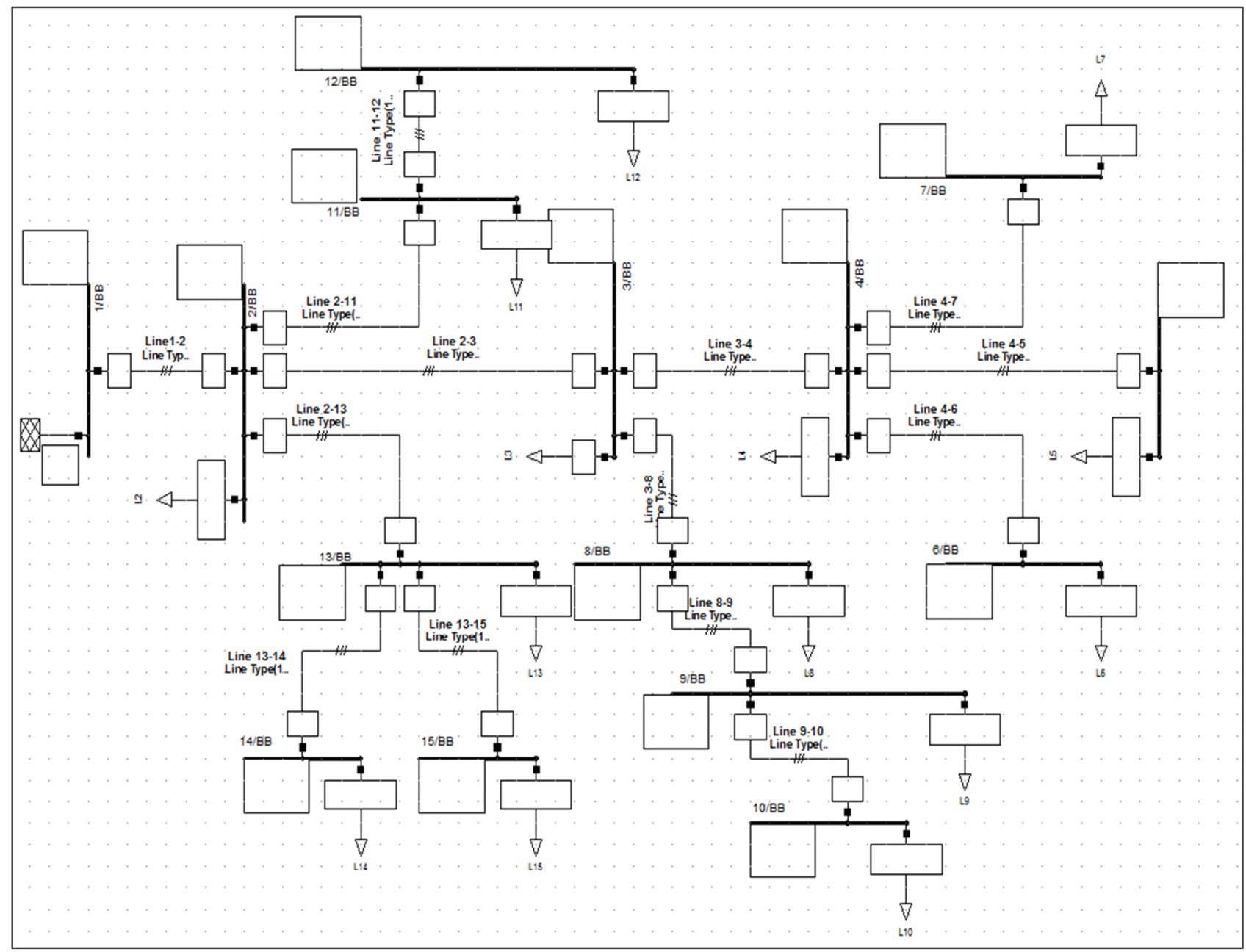

Figure 1: 15-node modelled in DIgSILENT Power Factory software 
From Figure 2, with an external infeed of 1.29 MW, 1.31 MVar, the Active power of the DG $=60$ percent of $1.29 \mathrm{MW}=0.774 \mathrm{MW}$

Reactive power of the DG $=40$ percent of $1.31 \mathrm{MVAr}$ $=0.524 \mathrm{MVAr}$

Under practical situations, the wind plant manufacturer will provide the $\mathrm{P}-\mathrm{Q}$ diagram of the generator at the point of coupling with the distribution network. It must be ensured that the wind turbine generator is equipped with adequate reactive power capability to achieve appropriate reactive power regulation. The assumption above, in the absence of the appropriate $\mathrm{P}-\mathrm{Q}$ diagram, is to ensure that sufficient reactive power is available to ensure satisfactory operation of the wind turbine generator. With a nominal voltage of $11 \mathrm{kV}$ and assumed power factor of 0.9 , the nominal apparent power of the DG can be calculated as:

$$
\begin{gathered}
\text { Apparent Power }(S)=\frac{\text { Active Power }}{\text { Power factor }}=\frac{0.774}{0.9} \\
=0.86 \mathrm{MVA}
\end{gathered}
$$

With the apparent power of 0.86 MVA, it was found that the synchronous generator was overloaded hence the value of 1 MVA was chosen instead. Other parameters were left at default values as shown in Figure 4.

Under practical purposes an optimal allocation of DG, taking into account physical constraints such as available capacity, costs, location and size etc will be carried out first to determine the appropriate buses; this is the subject of further research. Also the default values of the synchronous generator as set in the software were used and no attempt was made to fine tune the control parameters. The dynamic interaction between the wind turbine generator and the distribution network was not modelled as the main interest in this paper is the steady state operation.

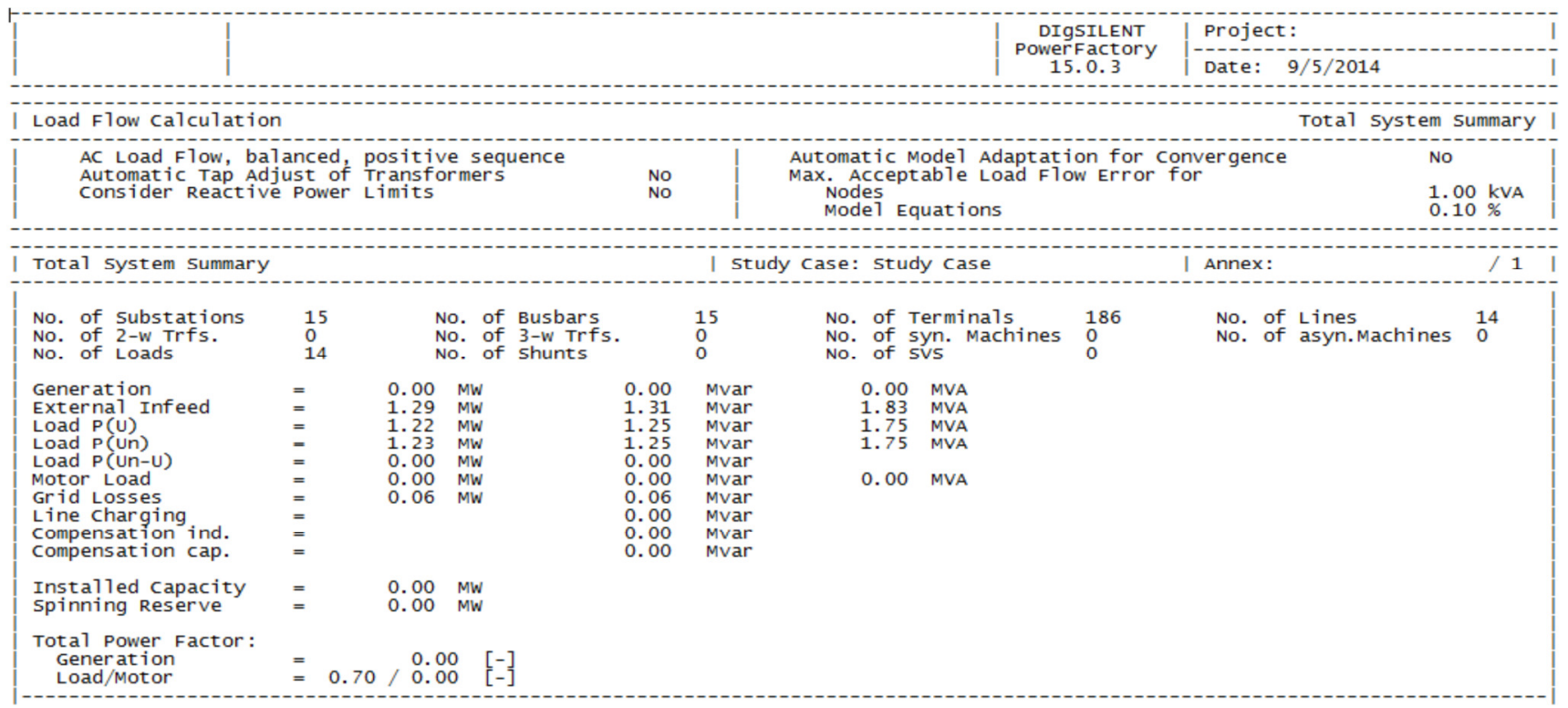

Figure 2: Total system calculation report before the introduction of DG

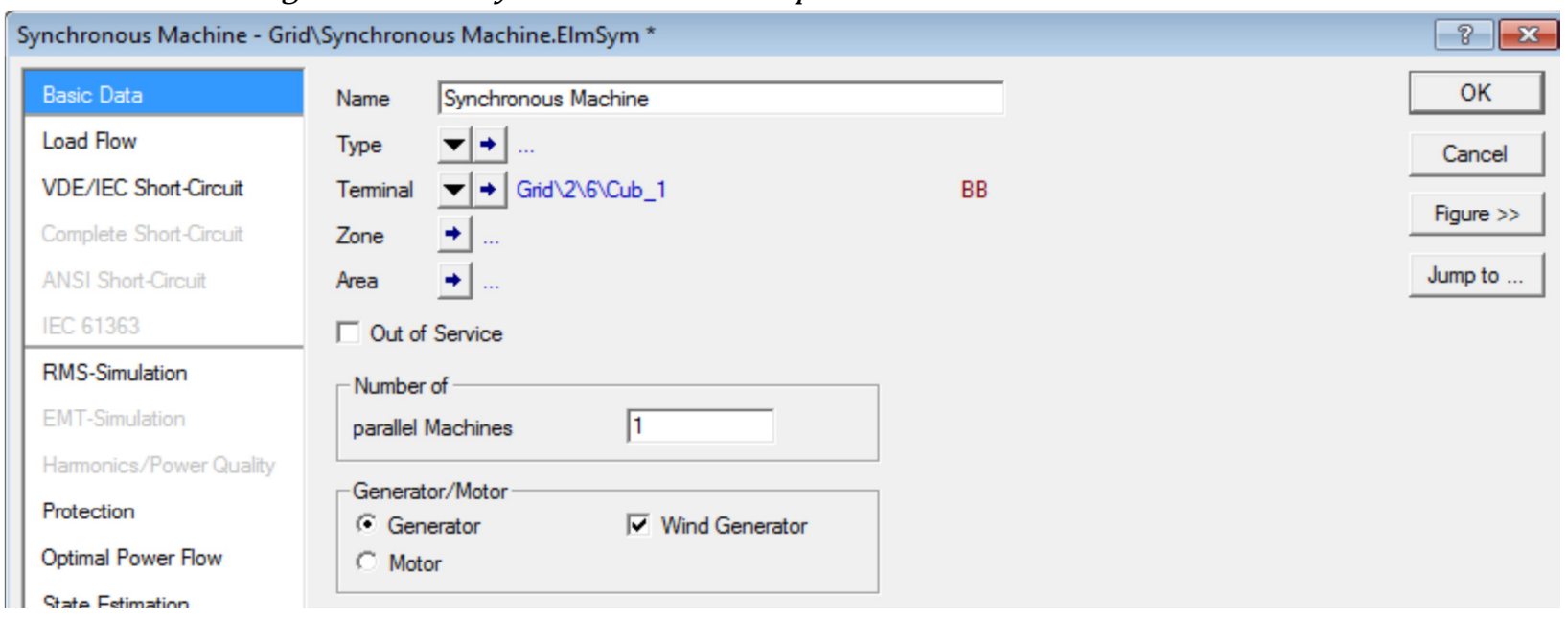

Figure 3: Synchronous Machine Basic Data 


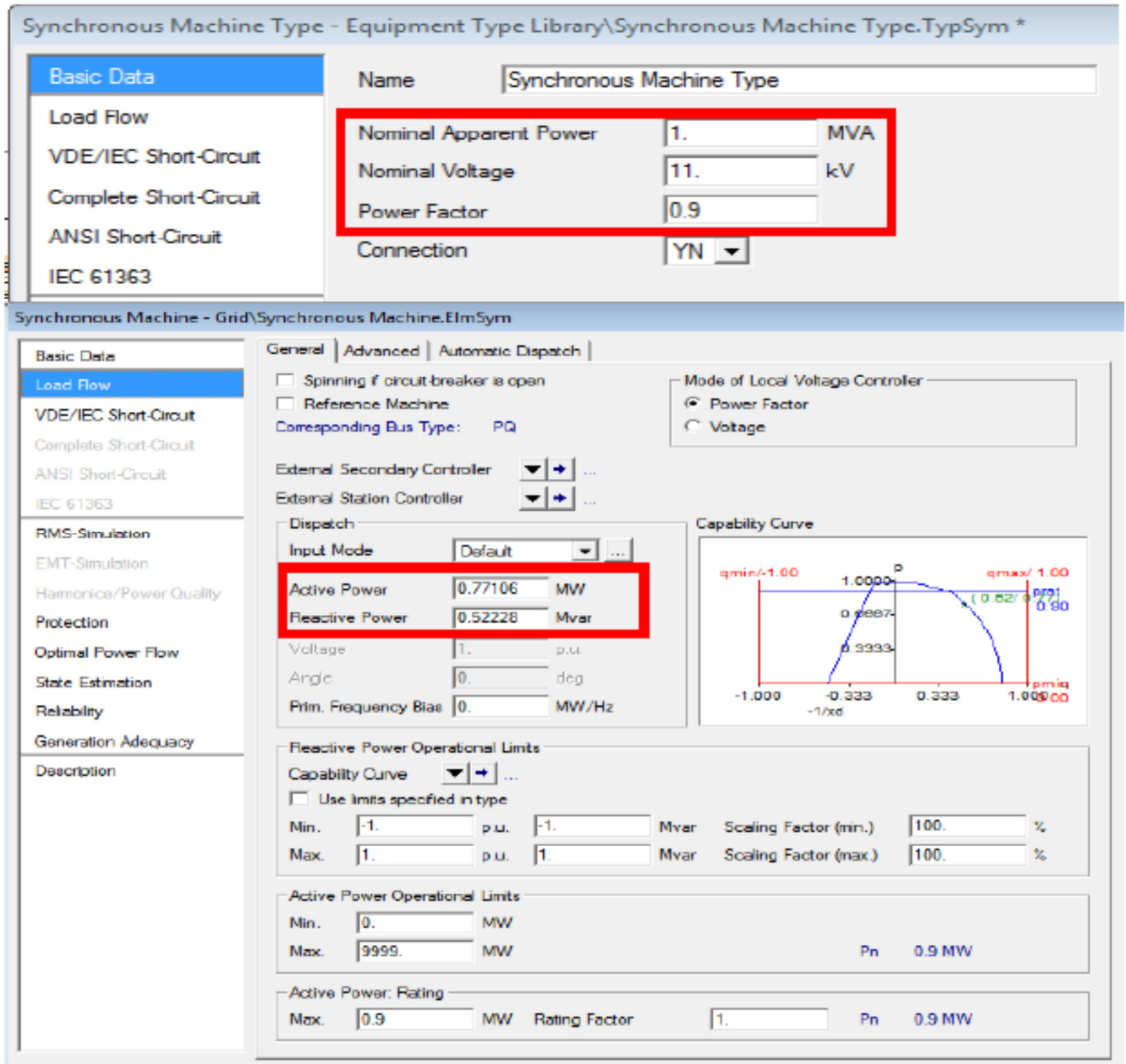

Figure 4: Synchronous Machine Data

\section{RESULTS}

\subsection{Reduction in Technical Losses}

Losses can be classified as technical or non-technical losses (comprising of illegal connections of electricity, metering errors and deficiencies, billing and processing errors etc) as shown in Figure 5. The combined losses could be up to $30 \%$ or more particularly in developing countries and this requires a major high level intervention. It has been shown in [2], using the transmission and distribution losses (\% of output) data compiled by the World Bank from 1971 to 2011 for some arbitrarily chosen developed and developing countries, that for most developed countries the technical losses are between $4 \%$ and $10 \%$. The subject of non-technical losses have been discussed elsewhere in [10] by Nwodo and Ekwue in 1992.
The results achieved by having no DG, placing the DG at either bus 2 or 4 are shown in Table 3 .

The line losses $=3 \times \mathrm{I}^{2} \mathrm{R}$

where $\mathrm{I}$ is the current and $\mathrm{R}$ the resistance of the line. The initial losses shown in Figure 2 as 0.06 MW from the load flow result has been validated in Table 3.

The technical losses have reduced from $0.06 \mathrm{MW}$ with no DG to $0.03 \mathrm{MW}$ when the DG was placed at bus 2 (i.e. $50 \%$ reduction) and to $0.02 \mathrm{MW}$ when placed on bus 4 (i.e. $67 \%$ reduction).

Further minimization of technical losses can be achieved by controlling the switchable reactive power sources, generator terminal voltages, transformer tap ratios and phase-shifters using a technique proposed in [13]. 


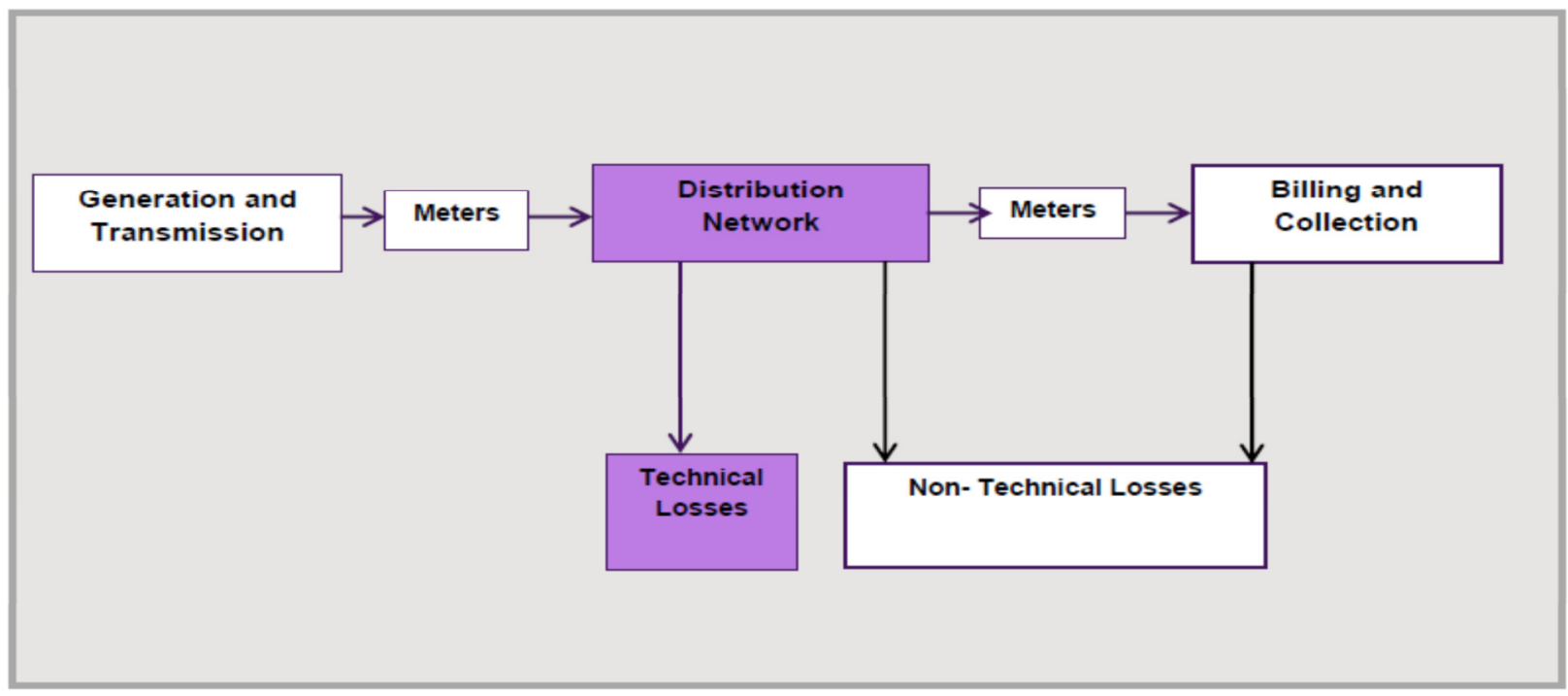

Figure 5: Typical Classification of Losses in a Distribution Network

Table 3: Comparison of line currents and technical losses with no DG, DG at bus 2 and DG at bus 4

\begin{tabular}{|c|c|c|c|c|c|c|c|c|c|}
\hline & & & & \multicolumn{2}{|c|}{ Before DG } & \multicolumn{2}{|c|}{ After DG inserted in bus 2} & \multicolumn{2}{|c|}{ After DG inserted in bus 4} \\
\hline $\begin{array}{l}\text { Sendin } \\
\text { g node }\end{array}$ & $\begin{array}{c}\text { Receivin } \\
\text { g node }\end{array}$ & $\begin{array}{c}\mathrm{R} \\
\text { (ohms) }\end{array}$ & $\begin{array}{c}\mathrm{X} \\
\text { (ohms) }\end{array}$ & $\begin{array}{c}\text { Current I } \\
(\mathrm{kA})\end{array}$ & $\begin{array}{c}\text { Technical Losses } \\
\text { (MW) }\end{array}$ & $\begin{array}{c}\text { Current I } \\
(\mathrm{kA})\end{array}$ & $\begin{array}{c}\text { Technical } \\
\text { Losses (MW) }\end{array}$ & $\begin{array}{c}\text { Current I } \\
(\mathrm{kA})\end{array}$ & $\begin{array}{c}\text { Technical } \\
\text { Losses (MW) }\end{array}$ \\
\hline 1 & 2 & 1.35309 & 1.32349 & 0.096 & 0.03741 & 0.047 & 0.00897 & 0.046 & 0.00859 \\
\hline 2 & 3 & 1.17024 & 1.14464 & 0.057 & 0.01141 & 0.056 & 0.01101 & 0.012 & 0.00051 \\
\hline 3 & 4 & 0.84111 & 0.82271 & 0.031 & 0.00242 & 0.031 & 0.00242 & 0.021 & 0.00111 \\
\hline 4 & 5 & 1.52348 & 1.0267 & 0.004 & 0.00007 & 0.003 & 0.00004 & 0.003 & 0.00004 \\
\hline 4 & 6 & 1.19702 & 0.8074 & 0.011 & 0.00043 & 0.011 & 0.00043 & 0.011 & 0.00043 \\
\hline 4 & 7 & 2.23081 & 1.5047 & 0.006 & 0.00024 & 0.005 & 0.00017 & 0.005 & 0.00017 \\
\hline 3 & 8 & 1.79553 & 1.2111 & 0.02 & 0.00215 & 0.02 & 0.00215 & 0.02 & 0.00215 \\
\hline 8 & 9 & 2.44845 & 1.6515 & 0.009 & 0.00059 & 0.009 & 0.00059 & 0.009 & 0.00059 \\
\hline 9 & 10 & 2.01317 & 1.3579 & 0.004 & 0.00010 & 0.003 & 0.00005 & 0.003 & 0.00005 \\
\hline 2 & 11 & 2.01317 & 1.3579 & 0.009 & 0.00049 & 0.009 & 0.00049 & 0.009 & 0.00049 \\
\hline 11 & 12 & 1.68671 & 1.1377 & 0.003 & 0.00005 & 0.003 & 0.00005 & 0.003 & 0.00005 \\
\hline 2 & 13 & 2.55727 & 1.7249 & 0.027 & 0.00559 & 0.027 & 0.00559 & 0.027 & 0.00559 \\
\hline 13 & 14 & 1.0882 & 0.734 & 0.011 & 0.00040 & 0.011 & 0.00040 & 0.011 & 0.00040 \\
\hline 13 & 15 & 1.25143 & 0.8441 & 0.006 & 0.00014 & 0.005 & 0.00009 & 0.005 & 0.00009 \\
\hline \multicolumn{5}{|c|}{ Total } & 0.06149 & & 0.03246 & & 0.02027 \\
\hline
\end{tabular}

\subsection{Improvement in Voltage Profile}

Before the introduction of distributed generation, lower voltages (i.e. below the stated 0.95 pu minimum value stipulated) were noted at buses 6, 7, 9 and 10. Bus 10 had the lowest voltage because it is farthest from the source (i.e. bus 1).

The voltages improved as the DG was inserted in bus 2 and then bus 4 as shown in Table 3. More system studies and results are available in [11] by Akintunde.

\section{CONCLUSIONS}

This paper has highlighted the benefits of distributed generation by using a 15-bus radial distribution network, modelled in the DIgSILENT Power Factory software, todemonstrate the improvement in voltage profile as well as the reduction in technical losses. Fixed (or no load, shunt or iron) losses as a result of hysteresis and eddy current losses in the iron core of transformers have not been included in this model. They are usually treated as constant and independent of network loading. Though only wind energy, as an example of a renewable source, was considered in this paper, similar conclusions will be reached by using other forms of renewable energy such as solar, biomass, geothermal etc. 
Table 3: Comparison of bus voltages with no DG, DG at bus 2 and DG at bus 4

\begin{tabular}{cccc}
\hline Bus & $\begin{array}{c}\text { Before } \\
\text { DG }\end{array}$ & $\begin{array}{c}\text { After DG inserted in bus } \\
2\end{array}$ & $\begin{array}{c}\text { After DG inserted in bus } \\
4\end{array}$ \\
\hline 1 & 1 & 1 & 1 \\
2 & 0.971 & 0.986 & 0.987 \\
3 & 0.957 & 0.972 & 0.985 \\
4 & 0.951 & 0.966 & 0.988 \\
5 & 0.95 & 0.965 & 0.987 \\
6 & 0.949 & 0.964 & 0.986 \\
7 & 0.949 & 0.964 & 0.986 \\
8 & 0.95 & 0.965 & 0.978 \\
9 & 0.946 & 0.961 & 0.974 \\
10 & 0.945 & 0.96 & 0.973 \\
11 & 0.968 & 0.983 & 0.983 \\
12 & 0.967 & 0.982 & 0.982 \\
13 & 0.958 & 0.973 & 0.974 \\
14 & 0.956 & 0.971 & 0.971 \\
15 & 0.957 & 0.972 & 0.972 \\
\hline & & &
\end{tabular}

The work described in this paper fits in with the Nigeria's Ministry of Power strategy of continued development of renewable energy sources and addressing high energy losses in the transmission and distribution networks.Future investigations will address the optimum allocation of DG taking into account physical constraints (such as cost, location etc) to reduce technical losses and improve on voltage profiles as well as the dynamic interaction between the wind turbine generator and the distribution network.

\section{ACKNOWLEDGEMENT}

The authors are grateful to Brunel Institute of Power Systems, Brunel University London for providing the facilities for carrying out the studies reported in this paper.

\section{REFERENCES}

[1] Ekwue A. O.,Nanka-Bruce O., Rao J. and McCool D., "Dynamic Stability Investigations of the Fault Ride Through Capabilities of a Wind Farm" Paper ID 99, Proceedings of the 16th Power Systems Computation Conference, 14 -18 July 2008, Glasgow.

[2] Ekwue A. O., "The role of R\&D in revitalizing an effective power system for sustainable development in Nigeria", Invited Symposium Paper presented at the $15^{\text {th }}$ Herbert Macaulay
Memorial Lecture, Faculty of Engineering, University of Nigeria, Nsukka on 20 June 2014, pp 1-16

[3] Turkish International Model United Nations (TIMUN'14) "Promoting Usage of Renewable Energy in Africa",

http://timun.gen.tr/wpcontent/uploads/2014/10/ECOSOC-Efe-Birkanrenewable-energy-Afrika.pdf (accessed on 24th November 2014)

[4] Department of Energy \& Climate Change, "UK Renewable Energy Roadmap Update 2012", 27th Dec2012, pp 1-67

[5]Begovic M., "Distributed Generation and Photovoltaics", presented in Dublin, Ireland in September 2011.

[6] Nebo C. and Kuchi H., "Federal Ministry of Power presentation at the Ministerial Platform for the period of May 2011 to May 2013 (July 23rd 2013)"

[7] Nnaji B.,"Power Sector Outlook in Nigeria: Government Renewed Priorities", June 2011 http://www.

sec.gov.ng/files/Prof\%20Nnaji\%20Presentation.p df, accessed on $14^{\text {th }}$ April 2014

[8] Ashokkumar R.and Aravindhababu P., "An Improved Power flow Technique for Distribution Systems," Journal of Computer Science, Informatics \& Electrical Engineering, vol. 3, no. 1, 2009, pp 1-8.

[9] Bousseau P.,Fesquet F.,Belhomme R.,Nguefeu S. and Thai T., "Solutions for the Grid Integration of Wind Farms - a Survey", Wind Energy published by John Wiley vol. 9, 2006, pp 13-25

[10] Nwodo T. C. and Ekwue A.O., "The effect of metering deficiencies on the economics and reliability of developing power systems", Proceedings of the 7th IEE International Conference on Metering Apparatus and Tariffs for Electricity Supply held in Glasgow, Nov. 1992 pp 1 $-4$

[11] Akintunde O. A., "Voltage Stability Analysis of Radial Distribution Networks", Unpublished M.Sc dissertation, Brunel University London. September 2014 pp 1 - 71

[12] DIgSILENT Power Factory 14.1 Software Manual (May 2011), vol. 1/2 and vol. 2/2

[13] Ekwue A.O., "Improved Real-Power Loss Minimisation", Nigerian Journal of Technology, vol. 9, no.1 September 1985, pp 31-37. 